\title{
Volcanogenic Tsunamis in Lakes: Examples from Nicaragua and General Implications
}

\author{
Armin Freundt, ${ }^{1,2}$ Wilfried Strauch, ${ }^{3}$ Steffen Kutterolf, ${ }^{1}$ and \\ Hans-Ulrich SChMincke ${ }^{1,2}$
}

\begin{abstract}
This paper emphasizes the fact that tsunamis can occur in continental lakes and focuses on tsunami triggering by processes related to volcanic eruptions and instability of volcanic edifices. The two large lakes of Nicaragua, Lake Managua and Lake Nicaragua, host a section of the Central American Volcanic Arc including several active volcanoes. One case of a tsunami in Lake Managua triggered by an explosive volcanic eruption is documented in the geologic record. However, a number of events occurred in the past at both lakes which were probably tsunamigenic. These include massive intrusion of pyroclastic flows from Apoyo volcano as well as of flank-collapse avalanches from Mombacho volcano into Lake Nicaragua. Maar-forming phreatomagmatic eruptions, which repeatedly occurred in Lake Managua, are highly explosive phenomena able to create hugh water waves as was observed elsewhere. The shallow water depth of the Nicaraguan lakes is discussed as the major limiting factor of tsunami amplitude and propagation speed. The very low-profile shores facilitate substantial in-land flooding even of relatively small waves. Implications for conceiving a possible warning system are also discussed.
\end{abstract}

Key words: Lake tsunami, volcanogenic tsunami, tsunami hazard, Nicaraguan lakes.

\section{Introduction}

Tsunamis are widely recognized as disastrous waves in the ocean triggered by earthquakes, particularly since the Dec. 26, 2004 catastrophe in the Indian Ocean. This paper aims to draw attention to the facts that volcanic processes also trigger tsunamis, and that such disastrous waves do also occur in lakes on land. The best documented and most disastrous volcanogenic tsunami catastrophe in recorded history occurred during the 1883 eruption of the Krakatau Volcano in Indonesia. Almost 30,000 lives were taken along the Sunda Strait shores by tsunamis formed when voluminous pyroclastic flows entered the sea around the volcanic island of Krakatau (CAREY et al., 2001). Pyroclastic flows also caused tsunamis at many

\footnotetext{
${ }^{1}$ SFB 574 at Kiel University, Wischhofstr. 1-3, D-24148, Kiel, Germany.

2 IFM-GEOMAR, Wischhofstr. 1-3, D-24148, Kiel, Germany.

${ }^{3}$ Instituto Nicaragüense de Estudios Territoriales, INETER, Managua, Nicaragua.
} 
other volcanoes such as Tambora in 1815 (SELF et al., 1984; SiguRdSSON and CArey, 1989), Aniakchak, Alaska (Waythomas and Neal, 1998), Santorini, Greece (McCoy and Heiken, 2000), most recently at Montserrat, Lesser Antilles (Hart et al., 2004; Pelinovsky et al., 2004), and at many other locations (DE LANGE et al., 2001). Similar to pyroclastic flows, avalanches from collapsing flanks of stratovolcanoes can trigger tsunamis when entering water or when the debris masses move largely under water as on the flanks of volcanic ocean islands (e.g., Keating and McGuire, 2000). Such collapses can be triggered by volcanic or tectonic activity but also by climatic events (e.g., KERLE and VAN WYK DE VRIES, 2001; SCOTT et al., 2005). In 1792, an earthquake-triggered collapse at Unzen, Japan, shed an avalanche into the Ariake Sea where it formed a tsunami; more than 14,000 lives were lost (SIEBERT, 2002). Apart from these two types of mass flows, volcanoes provide other potential trigger mechanisms of tsunamis such as caldera subsidence and other volcano-tectonic movements or underwater explosions (BEGET, 2000).

One type of tsunami has yet received little scientific attention although it can also be disastrous, albeit on a more local scale. This is tsunamis in continental lakes. A prominent volcanic example is the initial landslide of the May 18, 1980, Mount St. Helens eruption, which entered Spirit Lake and caused water run-up to $260 \mathrm{~m}$ above lake level (VoIGHT et al., 1981). In 1999, a relatively small landslide caused a 15-mhigh wave in the shallow crater lake of Kasu Tephra Cone, Papua New Guinea, injuring several people and killing one (WAGNER et al., 2003). Underwater explosions in Lake Karymskoye, Kamchatka, in 1996 formed tsunamis with 2-30 m run-up heights at shore (BELOUSOv et al., 2000). Naturally, non-volcanic landslides do also generate tsunamis in lakes. Fatal examples of landslide-triggered lake tsunamis occurred in 1971 in Lake Yanahuin, Peru (PlAFKER and EYZAGUIRRE, 1979), and 1987 in the Valtellina valley, Italian Alps (Govi et al., 2002). A 60-m-high wave formed by a landslide into the Vaiont reservoir, northern Italy, in 1967 drowned more than 2000 people (MüLLER, 1964). Glacier falls can likewise trigger catastrophic tsunamis (SLINGERLAND and Voight, 1979). Moreover, lake tsunamis may be triggered by earthquakes. Tectonic movement at a fault crossing a lake can form a tsunami and, if the lake is deep and has steep margins, also excite seiches which may flood the shores hours after the earthquake and tsunami (ICHINOSE et al., 2000). Model results for the 500-m-deep Lake Tahoe (USA) indicate higher amplitudes for the seiches than the tsunami, and smaller seiches also form by resonance induced by earthquakes on faults $10-\mathrm{km}$ away from the lake (ICHINOSE et al., 2000). Fatal seiches destroyed villages at Taal Caldera Lake, Philippines, following a tectonic earthquake in 1749 (NEwHALL and DzURISIN, 1988). In 1878 and 1937, earthquakes associated with vertical ground motions triggered tsunamis in Rabaul caldera, Papua New Guinea, which forms a shallow bay (NEwhall and DZURISIN, 1988). 
In lakes as well as in largely enclosed bays and inlets the travel times of tsunamis to threatened shores are short. Early warnings will thus mainly depend on timely recognition of the potentially tsunami-triggering events.

\section{Tsunamis in Nicaragua}

Since 1500, the number of 49 tsunamis is known to have occurred on the Central American Pacific and Atlantic Coasts (MolinA, 1997); all generated by strong tectonic earthquakes. The largest and most destructive tsunami impacted on September 1, 1992, on the Nicaraguan Pacific Coast with wave heights up to 10 meters. The tsunami caused widespread destruction and killed more than 170 people. This event caused considerable interest in the Nicaraguan population on tsunami hazard, tsunami disaster prevention and mitigation, and was the starting point for the development of a National Tsunami Warning System for the Nicaraguan Pacific Coast. As Nicaragua has very large lakes the question arises whether tsunamis can occur in these lakes, which are the mechanisms to generate them, and whether early warning is possible for these events.

We have recently identified a tsunami deposit along the shore of Lake Managua that is related to a volcanic eruption (FREUNDT et al., 2006a) and which we will briefly describe below. At both lakes, Lake Managua and Lake Nicaragua (Fig. 1), potentially tsunamigenic volcanic events have occurred in the past; we describe some of these below.

Tsunamis in these lakes would differ from those in the ocean mainly because shallow water depths (Table 1) limit tsunami speed, amplitude and wavelength. Like ocean coasts, however, lake shores in Nicaragua and elsewhere are densely populated and at high risk when a tsunami occurs. We will discuss some aspects of lake tsunamis using the two large lakes in Nicaragua as examples. Both lakes lie within the line of active arc volcanoes and within the Nicaraguan depression, a tectonic graben roughly parallel to the trench where the Cocos Plate subducts beneath the Caribbean Plate.

\section{Tsunamigenic Events at the Nicaraguan Lakes}

\section{The Mateare Eruption}

The subplinian to plinian Mateare eruption occurred between 3,000 to 6,000 years ago from a now hidden vent near the northwestern shore of Chiltepe Peninsula in Lake Managua (FREUnDT et al., 2006a). Fossil shorelines found at Lake Managua (CowAN et al., 2002) imply that the lake's water level dropped through the past several thousand years such that the proposed Mateare vent site would have been under water of several meters depth at the time of eruption. The eruption produced a 


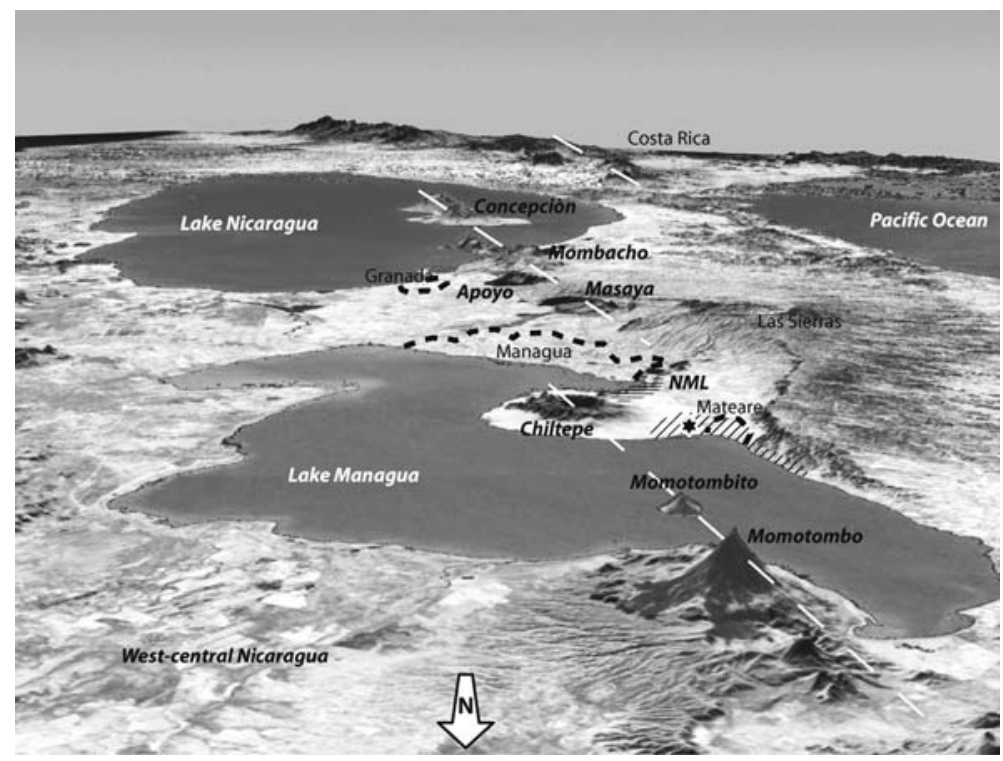

Figure 1

Oblique view, looking south, onto west-central Nicaragua with the two large lakes and chain of arc volcanoes. Modified from Google Earth. White dashed lines indicate linear segments of the volcanic front that are offset between Chiltepe Peninsula and Masaya volcano, and near the Nicaragua-Costa Rica frontier. NML is the Nejapa-Miraflores lineament, with the horizontally hatched area indicating the distribution of phreatomagmatic maar deposits. The diagonally hatched area around Mateare indicates the distribution of a tsunami deposit associated with a plinian eruption from a proposed vent site marked by the star.

dacitic to andesitic, compositionally zoned pumice lapilli fallout deposit-the Mateare Tephra - that is about 2-m thick and exposed along the shore of Lake Managua north of the town of Mateare over a distance of about $15 \mathrm{~km}$ (Fig. 1). We

Table 1

Properties of the two large Nicaraguan lakes. Data from World Lakes Database (www.ilec.or.jp), 2004

\begin{tabular}{ccc}
\hline Properties & Lake Nicaragua & Lake Managua \\
\hline Length $(\mathrm{km})$ & 160 & 58 \\
Width, $\mathrm{W}(\mathrm{km})$ & 70 & 22 \\
Area $\left(\mathrm{km}^{2}\right)$ & 8150 & 1016 \\
Volume $\left(\mathrm{km}^{3}\right)$ & 108 & 8 \\
Avg. depth $(\mathrm{m}) *$ & 13 & 8 \\
Max. depth, $\mathrm{D}_{\max }(\mathrm{m})$ & $70^{* *}$ & 26 \\
Avg. slope tan $\alpha=2^{*} \mathrm{D}_{\max } / \mathrm{W}$ & 0.0020 & 0.0024 \\
Avg. wave celerity, $\mathrm{c}(\mathrm{m} / \mathrm{s})$ & 11 & 9 \\
\hline
\end{tabular}

* Volume divided by area.

** Note that low-resolution bathymetric data from Direccion Hidrografia de Instituto Nicaragüense de Estudios Territoriales (INETER), Managua, suggest a maximum depth of only $\mathrm{D}_{\max }<30 \mathrm{~m}$. 
have divided the deposit into four units (FREUNDT et al., 2006a). Unit A is a well-stratified fallout of high-silica dacitic pumice with relatively high contents of ash and lithic fragments (Fig. 2). It is interpreted as the result of an early phase of eruption characterized by discrete explosions which appear to have been caused by both interaction with external water and temporary blocking of the vent by obsidian plugs. Unit B is a well-sorted, massive and lithic-poor light-gray dacitic pumice lapilli fallout that constitutes the major thickness of the deposit (Fig. 2). It represents the main, steady plinian phase of the eruption. Unit $\mathrm{C}$ is a continuation of unit $\mathrm{B}$ in terms of grain size and texture but is composed of black andesitic pumice. The change in composition occurs over a thin thickness interval. The rapid change in magma composition did not interrupt or significantly modify the continuing eruption. Unit D has a lapilli fallout layer at base composed of vesicle-poor andesitic scoria, some earlier erupted and entrained pumice lapilli, and lithic fragments. It is overlain by a stratified package of fallout ash rich in accretionary lapilli. Unit D represents fallout from the phreatomagmatic terminal eruption phase. The top of the Mateare Tephra has commonly been eroded, and basal unit A is missing in most outcrops along the lake shore.

A dark-gray sand layer, the Mateare Sand, lies stratigraphically between units A and B of the Mateare Tephra (Fig. 2); in the common absence of unit A, however, it lies at the base below unit $\mathrm{B}$. This medium sand $\left(\mathrm{M}_{d_{\Phi}}=1.8-2.2\right)$ is well sorted $\left(\sigma_{\Phi}=0.95-1.85\right)$ but contains outsized pumice lapilli either dispersed in the sand or forming pumice lenses. This light-gray pumice is mostly derived from the Mateare Tephra although there is a minor contribution of white pumice from the underlying, compositionally distinct Xiloa Tephra. The sand-size fraction contains angular vesicular through dense glassy fragments of Mateare dacite, rounded particles of Xiloa pumice, fragments of dacitic and basaltic lavas, and crystal fragments. Apart from the dominant Mateare dacite fraction, the composition of the sand is similar to that of modern beach sand at the shore of Lake Managua near Mateare. The Mateare Sand has wavy lower and upper contacts and is $5-20 \mathrm{~cm}$ thick in flat areas (Fig. 2) but locally forms thick fills of channels directed toward the lake. While mostly massive in the overbank facies, the channel fills show chaotic bedding with lenses of pumice lapilli. The sand layer can be traced to elevations up to $32 \mathrm{~m}$ above the present lake level. At the most elevated outcrops, molds from tree logs are surrounded by sediment aggradation structures interpreted to have formed as sand piled up against stranded driftwood poles.

The well-sorted sand is a water-lain deposit forming a widespread sheet along the shore of Lake Managua. It is not a beach sand because it reaches to elevations exceeding plausible beach levels even considering that the lake level was $9 \mathrm{~m}$ above present level $\sim 6300$ years ago (CowAN et al., 2002), and underlying unit A of the Mateare Tephra was not emplaced in water but on dry land. Since the deposit formed during the Mateare eruption, we have interpreted it as a volcanogenic tsunami deposit. The timing of tsunami formation can be deduced from the composition of 

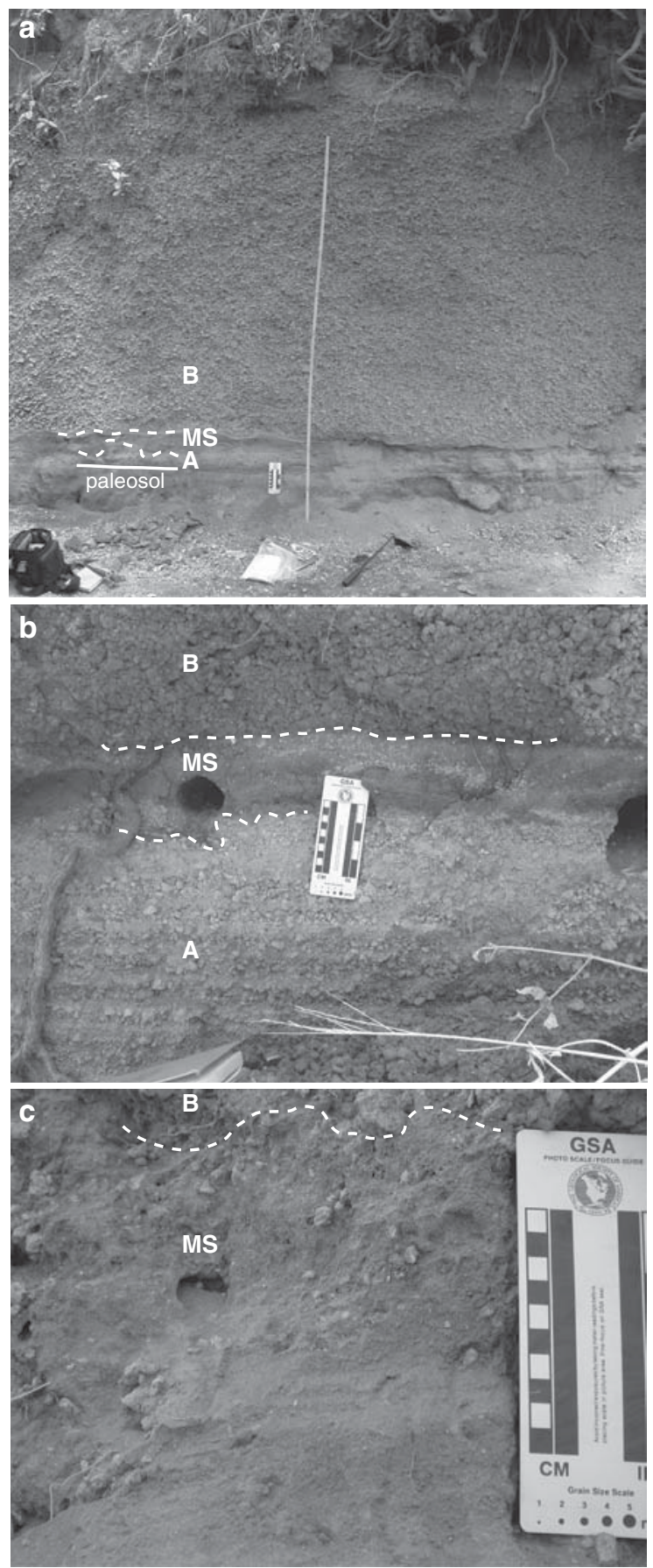
Figure 2

The Mateare Tephra including the Mateare Sand, a volcanogenic tsunami deposit. (a) Condensed tephra unit A erosively overlain by the sand (MS) which is covered by the massive pumice fallout unit B. Long scale is $2 \mathrm{~m}$. Locality A71. (b) The thickest exposure of stratified fallout unit A, erosively overlain by the sand MS which contains molds from former driftwood logs. Massive unit B at top. Locality A114. (c) Detail of the massive sand with dispersed pumice lapilli. Locality A75. Localities and minimum distribution of sand layer are indicated in Figure 4.

the entrained Mateare pumice, making use of the chemical zonation of the deposit (FREUNDT et al., 2006a). The composition of batches of pumice lapilli collected from the Mateare Sand is typically a mixture of unit-A and unit-B compositions, which are separated by a compositional gap in the primary fallout (Fig. 3a). The composition of pumice in the sand differs between outcrops such that the unit-B contribution decreases toward higher elevation above the lake (Fig. 3b). Hence, early tsunami waves mostly eroded unit A near shore and reached the highest run-up whereas closer to shore subsequent weaker tsunami waves lasted longer into unit-B eruption. The tsunami effect of inhibiting fallout emplacement of early unit-B pumice varied locally as shown by the variable composition of pumice at the very base of unit B (Fig. 3); this probably reflects topographic control on wave run-up and channeling. The late waves may have been separate tsunamis or waves reflected at the lake shores; we favor the first interpretation since the very gentle shore slopes would largely
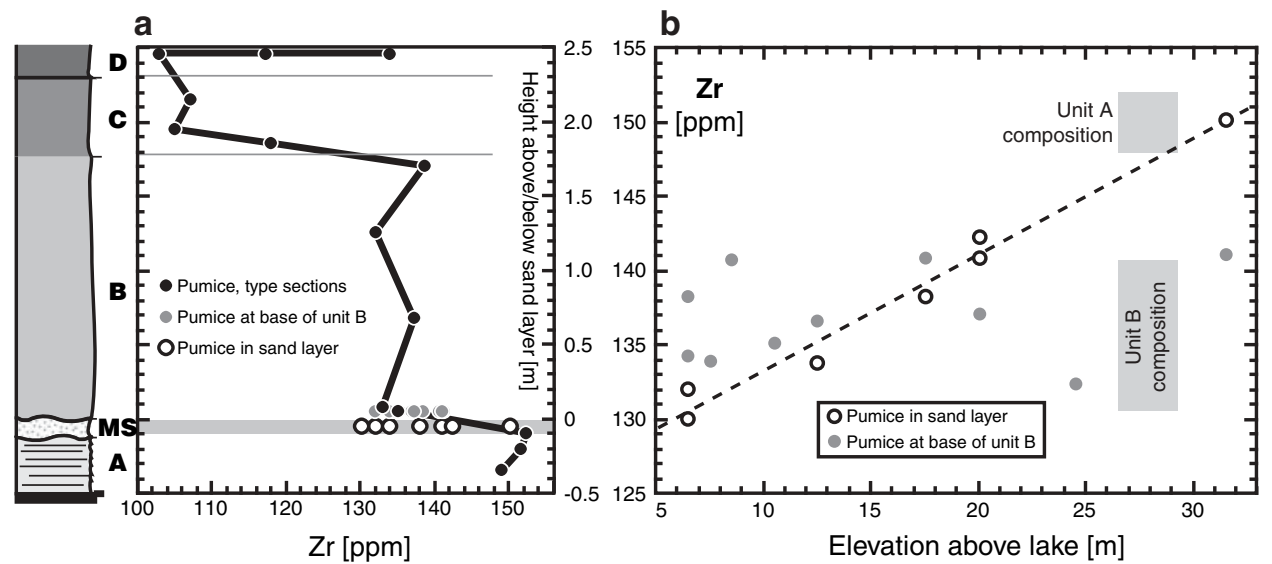

Figure 3

(a) Vertical chemical zonation of the Mateare Tephra using bulk-rock Zirconium content (black dots) as an example. The wide compositional range in phreatomagmatic unit $\mathrm{D}$ is due to re-entrainment of earlier erupted pumice. Composition at the exposed base of unit B (gray dots) differs between outcrops; the basal contact of B is thus not time-equivalent between outcrops. White dots are the bulk composition of batches of pumice lapilli collected from the sand layer; they bridge the gap between unit A and B compositions. (b) Composition at the base of unit B varies irregularly, but pumice in the sand systematically changes from unit B to unit A composition with elevation above the lake. Hence, more unit B material was entrained in the sand closer to shore. 
dampen reflections. The interval of tsunami formation appears to be associated with the early unsteady phase of eruption, particularly when obsidian plugs blocked the vent and were violently disrupted, leaving abundant obsidian fragments in the deposit at this stratigraphic level. The detailed processes of tsunami formation remain unknown because the near-vent area is not exposed. There is no evidence that potentially tsunamigenic mass flows formed in this eruption, which occurred at a vent in flat land rather than from a volcanic cone. Subsidence at the vent is unlikely at a time when a stable plinian eruption column was forming and emplaced lithic-poor fallout. This leaves explosive processes as possible tsunami triggers. The Mateare Sand is the first documented tsunami deposit at a Nicaraguan lake and its importance is in showing that this type of volcanic hazard can occur and may affect significant areas along the gently sloping lake shores (Fig. 4).

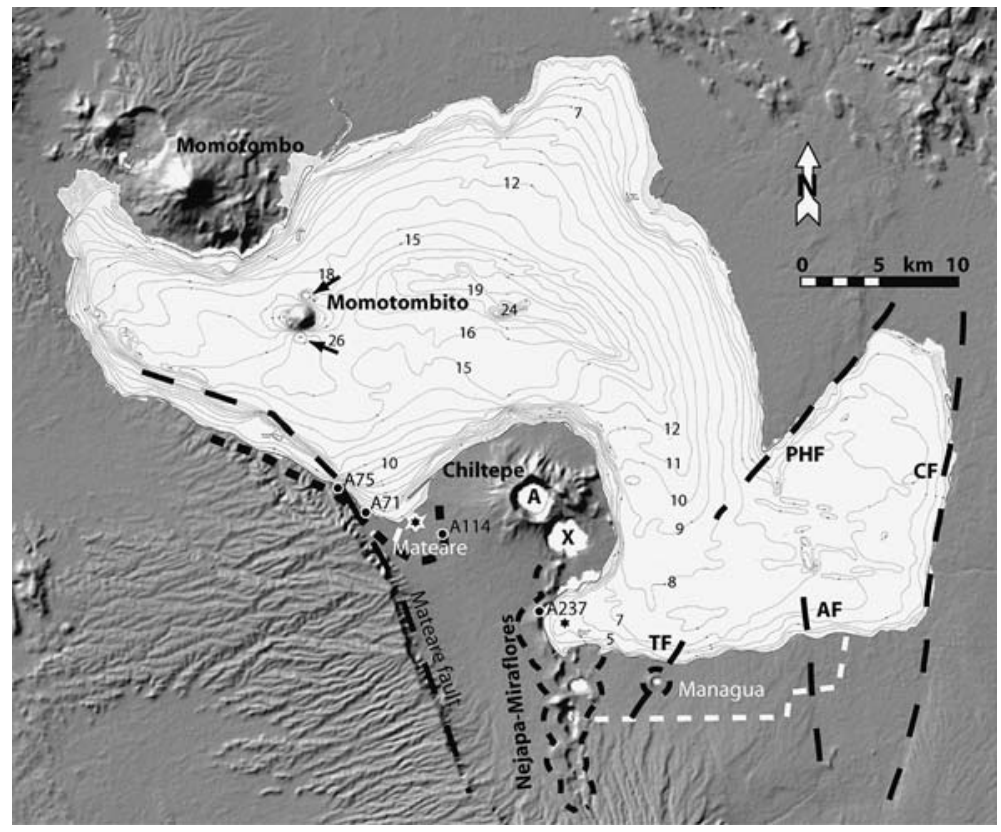

Figure 4

DEM of the area around Lake Managua. Superimposed bathymetry from 1979 map of INETER, Managua. Depths in meters. Note deep pits near Momotombito. The Mateare Fault is the western boundary of the Nicaraguan Depression; bathymetry suggests it curves westward within the lake. A = Apoyeque crater, $\mathrm{X}=$ Xiloa Maar. Bold dashed line near Mateare shows minimum distribution of Mateare Sand tsunami deposit; star marks proposed vent site of Mateare Tephra. A71, A75, A114, A237 are localities shown in Figures 2 and 5. Thin dashed lines along Nejapa-Miraflores lineament indicate distribution of phreatomagmatic maar deposits. Star in the SW bay of the lake suggests one or more vent sites on the lake floor. Major tectonic faults extending into the lake include the Punta Huete Fault (PHF), Cofradias Fault (CF), Aeropuerto Fault (AF), and Tiscapa Fault (TF) which was active during the 1972 earthquake (BROwN et al., 1973). Numerous minor faults dissect the whole area. 


\section{Phreatomagmatic Eruptions in Lake Managua}

The NW-SE trending linear volcanic front is offset between Chiltepe Peninsula and Masaya Volcano (Fig. 1), a region that corresponds to a segment boundary as defined by CARR (1984). The offset limbs of the front are connected by the N-S trending Nejapa-Miraflores lineament, a zone of numerous maars and cinder cones, that extends from west of Managua to the southern part of Chiltepe Peninsula, cutting across the southwestern bay of Lake Managua (Fig. 4). Within the thick pyroclastic succession, packages of phreatomagmatic deposits are separated by intercalated widespread dacitic tephra beds (Fig. 5), some of which we have dated.

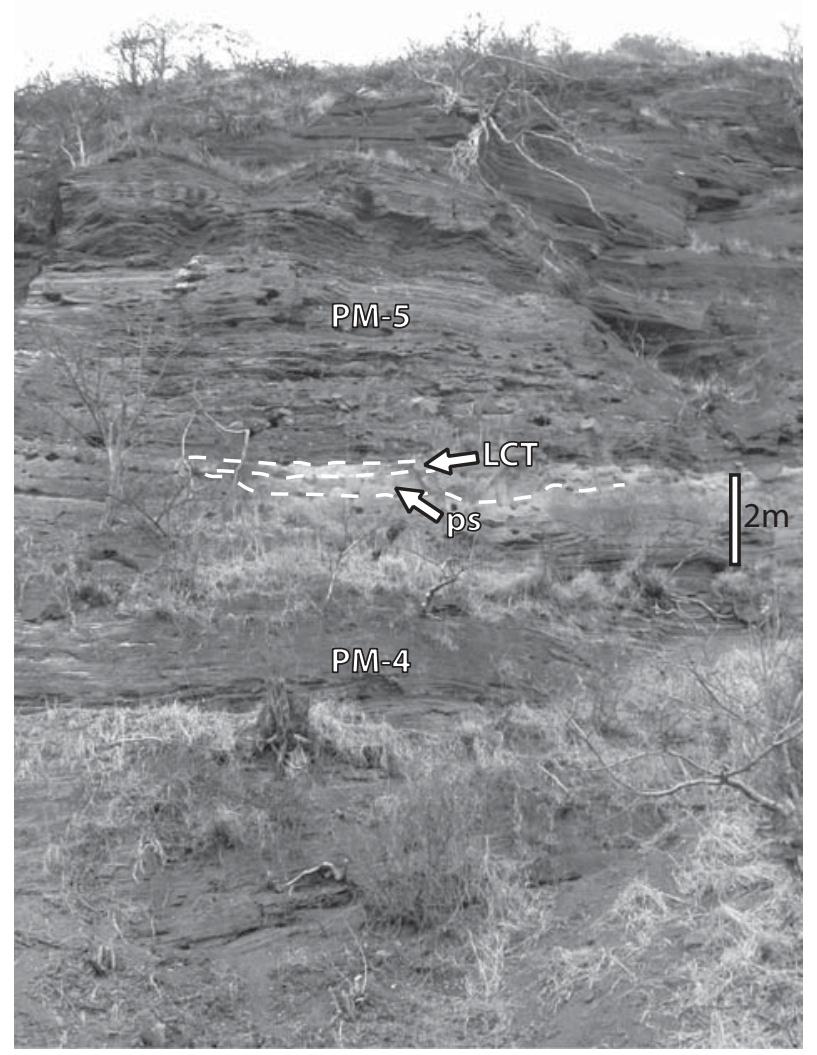

Figure 5

Phreatomagmatic deposits from maar-forming eruptions exposed in a cliff along the western shore of the SW bay of Lake Managua (Loc. A237 in Fig. 4). Pale band above massive paleosol (ps) is the Los Cedros Tephra (LCT), a dacitic pumice fallout that is approximately 2,500 years old. PM-4 and PM-5 are thick packages of well-stratified phreatomagmatic deposits that include major unconformities and are thus each the product of more than one maar eruption from vents on the floor of the SW bay of Lake Managua

(Fig. 4). 
Our stratigraphic investigations show that activity along the Nejapa-Miraflores lineament ranged from $>13,000$ to $<2,000$ years and is thus likely to continue (FrEUNDT et al., 2006b). A continuous cliff along the west shore of the SW bay of Lake Managua exposes thick successions of basaltic maar deposits that formed by numerous vigorous explosions when the hot magma encountered surface water (Fig. 5). Although a detailed study of the phreatomagmatic maar deposits is necessary yet, reconnaissance data suggest their source vents lie in the SW bay of the lake which is only $<7 \mathrm{~m}$ deep (Fig. 4). Phreatomagmatic eruptions in Lake Managua would be capable of producing hazardous tsunamis similar to those observed during the phreatomagmatic eruptions in Lake Karymskoye in 1996 (Belousov et al., 2000) or reported from the Taal Caldera Lake, Philippines, during phreatomagmatic eruptions in 1716, 1754 and 1911 (NEWHALL and DZURISIN, 1988).

The young volcanic cone of Momotombito in the northern part of Lake Managua has not yet been investigated but it is clearly a growing volcano. Its future eruptions and associated volcanotectonic movements could be tsunamigenic. The bathymetric map of Lake Managua shows two circular holes immediately north and south of the cone which might be craters from subaqueous explosions (Fig. 4). There is clear need for more detailed bathymetric and seismic studies to unravel volcanic vents and tectonic structures in the floor of Lake Managua.

\section{The Apoyo Ignimbrite}

Apoyo Caldera, $35 \mathrm{~km}$ southeast of Managua in Central Nicaragua (Fig. 1), is a large $(6.5 \mathrm{~km}$ diameter), deep $(c . \sim 600 \mathrm{~m})$ circular volcanic subsidence basin (Sussman, 1985). Two large-magnitude plinian eruptions in rapid succession formed the present caldera structure c. $24 \mathrm{ka}$ ago and produced the Lower and Upper Apoyo Tephras. The c. $30 \mathrm{~km}^{3}$ volume of the Upper Apoyo Tephra includes c. $8.5 \mathrm{~km}^{3}$ of ignimbrite (SUSSMANN, 1985) exposed in the lowlands south and east of the caldera up to the shore of Lake Nicaragua. Average thickness is about $20 \mathrm{~m}$ but locally the ignimbrite is 55-m thick (Fig. 6). The city of Granada was built on these deposits which are unwelded but cemented by vapor phase mineralization and contain abundant degassing pipes, evidence that their depositing pyroclastic flows were hot.

Exposures of up to 20-m-thick ignimbrite along the shore show that the pyroclastic flows continued into the lake. The pyroclastic flows climbed $100 \mathrm{~m}$ high up the northern flank of Mombacho volcano at 5-km distance from Apoyo caldera, allowing SUSSMAN (1985) to estimate a velocity of $65 \mathrm{~m} / \mathrm{s}(240 \mathrm{~km} / \mathrm{h})$. The ignimbrite is composed of several flow units (deposits from successive pyroclastic flows; Fig. 6a), each about 4-m thick at the lake shore. The flows entered the lake along a $15-\mathrm{km}$ length of shore. The volume flux into Lake Nicaragua can thus be roughly estimated as $3 * 10^{6} \mathrm{~m}^{3} / \mathrm{s}$ although the total volume of tephra discharged into the lake remains unknown. 

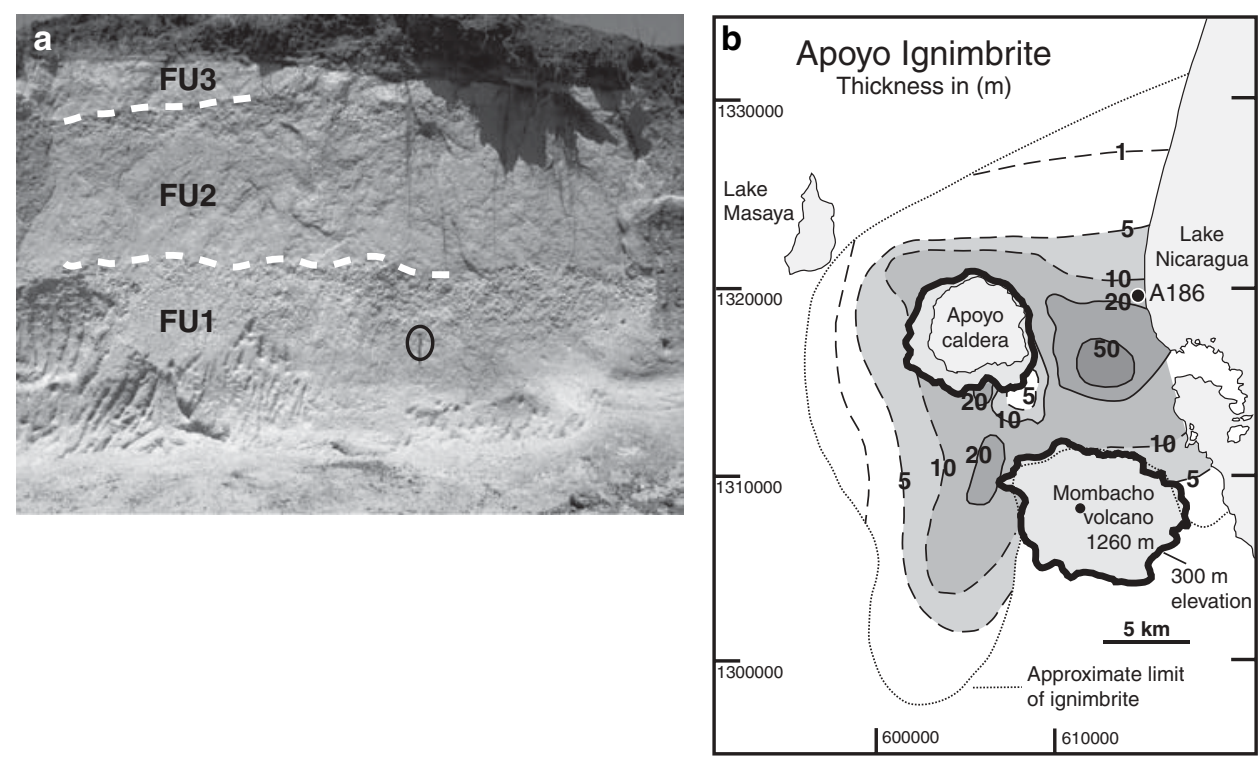

Figure 6

(a) Outcrops of three massive flow units (FU) of Apoyo Ignimbrite at the north rim of Granada City and close to the shore of Lake Nicaragua (Loc. A186 in b). Circle marks Hammer $(40 \mathrm{~cm})$ for scale. (b) Isopach map of the Apoyo Ignimbrite modified from Sussman (1985). Major entrance of pyroclastic flows into Lake Nicaragua occurred along more than $15 \mathrm{~km}$ length of shore. The curved peninsula in the lake is composed of a debris avalanche from Mombacho volcano (cf. Fig. 7). Coordinates are UTM values.

\section{Volcano Flank Collapses and Mass-wasting Events}

Volcán Mombacho is located at the northern end of Lake Nicaragua near Granada (Figs. 1, 6), the second largest city in Nicaragua. Mombacho has erupted explosively in prehistoric times to form widespread ash-fall deposits, and repeated instability of the large cone also generated huge debris avalanches. Debris flow deposits at Mombacho volcano indicate that at least three large prehistoric flank collapses did occur (VALLANCE et al., 2001a). The three massive debris avalanches extend about $10 \mathrm{~km}$ from the summit to the southeast, northeast and south. The large $\left(20-30 \mathrm{~km}^{2}\right)$ hummocky debris lobes resulting from the final two events form small islands in Lake Nicaragua (Fig. 7; Vallance et al., 2001a). The last of these debris avalanches occurred at $c$. AD 450 (Dull et al., 2005). Present-day Mombacho is a deeply dissected volcano and its interior is probably structurally weakened by alteration of rocks in its long-lived hydrothermal system. Strongly hydrothermally altered regions in a volcano substantially reduce edifice stability, control the location of failure and may result in more voluminous and mobile avalanches (REID et al., 2001). Structural failure may be triggered by magmatic intrusions and eruptions but often is associated with external processes such as regional earthquakes, basal glide 


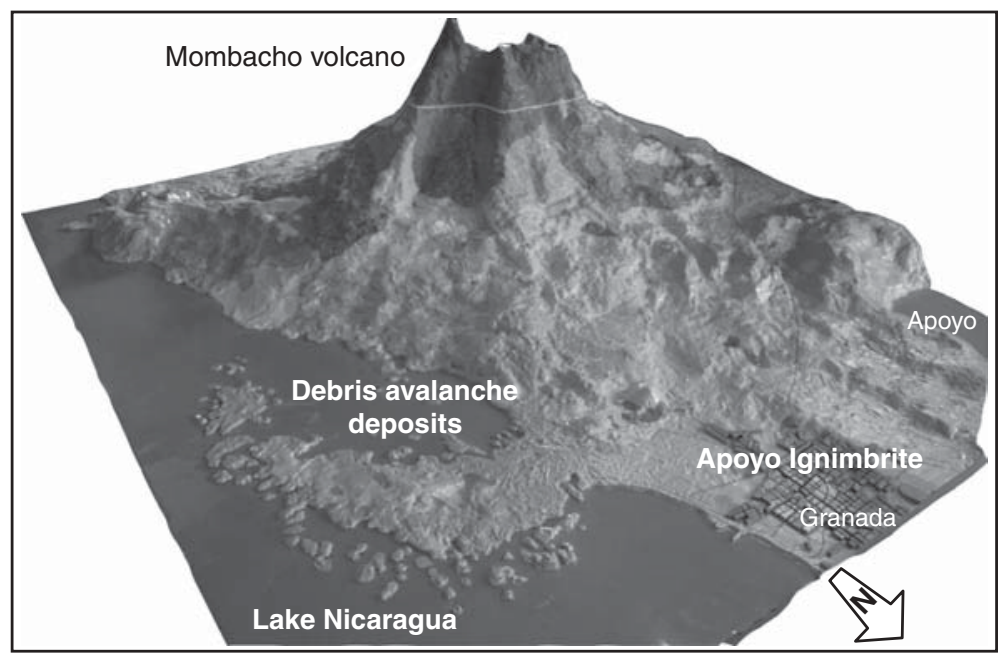

Figure 7

Model relief of Mombacho volcano showing the northwestern sector collapse scarp below the summit and debris avalanche deposits on the lower slopes and in Lake Nicaragua forming the curved peninsula and adjacent islets (which look very similar to the Tsukumo-shima islets formed by the 1792 landslide at Unzen volcano, Japan; Fig. 15 in SiEBert, 2002). The City of Granada rests on the flat surface of the Apoyo Ignimbrite that filled the valley north of Mombacho. Modified photograph of a model displayed in the Mombacho tourist information center.

planes on which a volcanic edifice may spread laterally, and, particularly, heavy precipitation which increases pore pressure in the edifice and may liquify the debris (MC Guire, 2003). Heavy precipitation during hurricane Mitch in 1998 triggered the debris flows at Casita Volcano in Nicaragua (VAllence et al., 2001b; ScotT et al., 2005). Debris avalanches from sector collapse can be particularly tsunamigenic when the collapse occurs in a catastrophic rather than piecemeal fashion. The intrusion of the Mombacho avalanches to at least $7 \mathrm{~km}$ into Lake Nicaragua (Fig. 7) most probably caused one or more tsunamis in the lake, although geologic evidence of such tsunamis has not yet been reported.

Concepción stratovolcano forms the northern half of Ometepe Island in Lake Nicaragua and rises $1600 \mathrm{~m}$ above the lake. Tectonic faults exposed on the shallower parts of the island indicate W-E extension and GPS measurements revealed radial but preferential westward spreading of the lower flanks. BorgiA and VAN WYK DE VRIES (2003) interpreted these data as gravitational spreading of the volcano under its own weight on the soft substrate of lake sediments. They concluded that such spreading would largely compensate stresses building up and thus reduce the risk of sector collapse but that, if a collapse were to occur, it would probably be on the western flank. There is only $10 \mathrm{~km}$ of lake water between the western shore of Ometepe and the city of Rivas on the west bank of Lake Nicaragua. 
Of the large stratocones close to the lake, Mombacho and Concepción are known to have produced numerous rain-triggered lahars during historic and prehistoric times (VALLANCE et al., 2001a, b). Both volcanoes are largely composed of pyroclastic material that is easily remobilized during torrential rains. Individual lahars may be small but can reach volumes of $10^{6} \mathrm{~m}^{3}$ (VALLANCE et al., 2001b). At Mombacho, a lahar similarly large as the one at Casita took 400 lives in 1570 (VALLANCE et al., 2001a). If such a large lahar entered the lake it could be tsunamigenic.

\section{Tsunamis in Lakes}

Tectonic faulting of the lake floor or intrusion of a mass flow displaces a volume of water from the area of movement. If the movement of such wavemakers is slow, the water can drain from the area relatively quietly. Conversely, if the wavemaking movement is fast, the water cannot drain quickly enough and a significant wave may build up (НАммАск, 1973). The capacity of water to drain from the interaction area is limited by the long-wave celerity $c=\sqrt{g D}$, which depends on water depth $D$, with $g$ the gravitational acceleration. Considering the 2-D case and assuming the wavemaker has a length scale, $L$, then the time scale of water moving from the wavemaking region is $L / c$. Wavemaking operates over a time scale $t_{w}$. The ratio of the time scales, the Hammack number $H a=t_{w} \cdot c / L$, must be $\mathrm{Ha}<<1$ to produce a tsunami by impulsive wave formation (WATTS, 1998; WALDER et al., 2003). These considerations show the important role in tsunami generation of the water depth, which is typically much shallower in lakes than in the ocean. For example, a wavemaker of $t_{w}=60 \mathrm{~s}$ and $L=2000 \mathrm{~m}$ in ocean water of $D=1000 \mathrm{~m}$ depth yields $\mathrm{Ha}=3$ whereas, in a lake of $D=20 \mathrm{~m}$ depth, the same wavemaker gives $\mathrm{Ha}=0.4$ and may impulsively form a tsunami. In this respect, shallow bays at ocean margins are similar to terrestrial lakes.

The energy of a wave is proportional to the square of its amplitude. The maximum wave amplitude is limited because higher waves break and dissipate their energy by turbulence. The breaking limit and the mode of breaking depend on the nature of the wave, its deep-water amplitude, and the slope of the bottom (DEAN and DALRYMPLE, 1991). Here we adopt the simple criterion that breaking occurs when wave amplitude exceeds $85 \%$ of the water depth. The shallow depth of lakes thus limits the energy that can be carried to greater distances by waves. The near-field wave amplitude generated by intruding mass flows has been investigated experimentally and theoretically. Early approaches mainly derived functions in which the dimensionless wave-crest amplitude $\eta=A / D$ is related to the Froude number $F r=u / c$ and the total volume, $V_{s}$, of the landslide (e.g., SLingerLand and Voight, 1979; see also review in FrITZ, 2002); $A$ is absolute amplitude and $u$ the slide velocity. In long flows, however, only the frontal portion acts to form a wave rather than the 
total volume. More recently, FRITZ (2002) has identified dimensionless wave amplitude as $\eta=n F^{m} \sigma^{p}$, where the ratio $\sigma=S / D$ of slide thickness, $S$, to water depth, $D$, is a dimensionless slide thickness, and $n=0.25, m=1.4$ and $p=0.8$ are constants from regression of experimental data. This solution treats landslide velocity, Fr, and depth, $\sigma$, independantly. WALDER et al. (2003) combined both parameters in the dimensionless slide volume flux per unit width, $q=Q / c D$, where $Q=u \cdot s$ is the 2-D volume flux and $c D$ is the limiting volume flux of water. Their experimental data is well regressed by the function $\eta=a \cdot q^{b}$ with the constants $a=1.32$ and $b=0.68$. WALDER et al. (2003) used solid boxes to simulate a landslide and identified $Q$ as the maximum volume flux. In experiments using granular flows intruding water (FREUNDT, 2003), waves formed and escaped from the region of interaction while the mass flow was still coming in. Using the initial volume flux as the relevant value of $Q$, observed wave amplitudes followed the power-law function of WALDER et al. (FREUndT, 2006). Moreover, modelling the flows as intruding granular jets yields the same form of function with the constants $1<a<1.2$ and $b=2 / 3$, providing a physical explanation of the above regression (FREUNDT, 2006).

The 2-D volume flux, $Q_{0.85}$, at which dimensionless amplitude reaches the limiting value $\eta=0.85$, depends on water depth, $\mathrm{D}$, as $\mathbf{Q}_{0.85}=2.13 \cdot \mathbf{D}^{3 / 2}$. The limiting volume flux would be only $Q_{0.85}=190 \mathrm{~m}^{2} / \mathrm{s}$ in a 20 -m-deep lake. Using the Apoyo Ignimbrite as an example, we obtain a volume flux per unit width of $Q=260 \mathrm{~m}^{2} / \mathrm{s}$ by dividing the bulk volume flux estimated above by the shore length of entry into Lake Nicaragua. Considering the average depth $D=13 \mathrm{~m}$ of Lake Nicaragua (Table 1), the volume flux of the Apoyo Ignimbrite was 2.5 times above the condition for formation of breaking waves. The average depth of Lake Managua is even lower at $D=8 \mathrm{~m}$ (Table 1); hence, a landslide descending, for example, from Momotombo volcano would only need a volume flux of $46 \mathrm{~m}^{2} / \mathrm{s}$ to reach the breaking-wave condition. For comparison, a 2-D volume flux of $100 \mathrm{~m}^{2} / \mathrm{s}$ can be estimated for the 1998 Casita debris flow that had a bulk volume flux of approximately $100,000 \mathrm{~m}^{3} / \mathrm{s}$ and was $1 \mathrm{~km}$ wide on the plain below Casita volcano (ScOTT et al., 2005). With the low average bottom slopes (Table 1) on which mass flows would intrude, the average water depth is reached at 3 to $6 \mathrm{~km}$ distance from shore in Lakes Managua and Nicaragua, respectively. When modelling the spreading of a tsunami in shallow lakes such as those in Nicaragua, the breaking-wave limit appears to be a reasonable starting point without the need to be more specific on the size of the triggering mass flow. In small lakes, however, where the intruding debris constitutes a significant fraction of the resident water volume and waves quickly reach opposing shores before much dissipation can occur, wave heights may well exceed the breaking-wave limit. Possible examples are the 15-m-high wave formed when a landslide intruded the crater lake of Kasu Tephra Cone, Papua New Guinea, which is mostly only $5 \mathrm{~m}$ deep with a maximum depth of $20-30 \mathrm{~m}$ but is also only $350 \mathrm{~m}$ long (WAGNER et al., 2003), and the 60-m-high wave formed by a non-volcanic landslide into the Vaiont Reservoir, Italy (MüLLER, 1964). 
Using wave celerities based on the average depths (Table 1), a tsunami triggered at Momotombito would reach Mateare within 25 mins and Managua after 70 mins; a tsunami due to an avalanche from Mombacho would reach Granada almost immediately and take about 90 mins to reach the eastern shores. Although waves travel relatively slowly in the shallow lakes, and the Nicaraguan lakes are quite large, warning times after a tsunamigenic event has started are very short, particularly for communities close to the site of tsunami formation. The flat, scarcely vegetated slopes along most of the lake shores offer little resistance to tsunami run-up.

\section{Conclusions}

\section{Population under Risk by Lake Tsunamis}

The population at the shores of Lake Managua is mainly concentrated in Managua itself, the capital of Nicaragua. Several thousand inhabitants of Managua could be affected by tsunamis triggered by volcanic explosions on or near Chiltepe Peninsula or by tectonic activity at the numerous active faults that dissect the lake bottom. Parts of the small town of Mateare could also suffer from tsunamis related to explosions at Momotombito volcanic island, or to explosions or flank-collapse avalanches at Momotombo volcano. At Mateare, the tsunami hazard would add to the volcanic hazards mainly arising from pyroclastic fallout dispersed in generally westerly directions by the prevailing winds. In comparison, the small village of San Francisco Libre on the northern shore of Lake Managua has only a minor hazard due to direct volcanic phenomena. But, as the beach has a very low profile, even a relatively weak tsunami could generate heavy damage.

Granada is the largest city on the shores of Lake Nicaragua. The city's shores and especially the hundreds of little islands of the "Isletas" - many of them populated - would be heavily affected by a tsunami generated anywhere in Lake Nicaragua. Another landslide from Mombacho volcano may cause extreme water run-up close to source as observed for the 1958 Lituya Bay, Alaska, event (MILLER, 1960). The island of Ometepe is another threatened place with respect to tsunamis because many people live nearby the lake on beaches with very shallow profile. Even the relatively large town of San Carlos, situated at the San Juan River on the southeastern shore of Lake Nicaragua, can be considered as endangered by tsunamis because the beaches are very low and population density is relatively high.

We mention that fast dangerous inundations similar to tsunamis could occur on the coasts of the large Nicaraguan lakes also due to meteorological effects (storm swells, especially if the meteorological disturbance passes the lake with a velocity similar to the average wave celerity) and seismic effects (seiches) due to near or distant very large earthquakes which generate oscillations of the water body with periods similar to the eigen-period of the lake. Seiches possibly occurred in 1844 in 
Lake Nicaragua (MolinA, 1997; FERNANDEZ et al., 2000) and were observed in April 1991 in Escondido River, Nicaraguan Atlantic Region, caused by the M = 7.1 El Limon earthquake in Costa Rica. Several major tectonic faults extend into Lake Managua (Fig. 4) which were active during Holocene to recent times (Brown et al., 1973; Cowan et al., 2002).

Future work in Nicaragua should include: (a) geological studies to identify fossil tsunami deposits around the lakes, (b) high-resolution bathymetry of the lakes as a prerequisite to apply numerical models of tsunami propagation (e.g., TINTI et al., 1999), and (c) shallow seismic study of the lake bottoms to identify tectonic structures and distribution of intruded mass flows. Such data will allow identification of possible source areas, spreading paths, and run-up heights of tsunamis which are needed for a useful tsunami hazard map.

\section{Possible Tsunami Warning System}

The efficiency of a tsunami warning system for the Nicaraguan Lakes depends much on the forewarning time span possibly available to people. To estimate this time we use wave celerities based on the average depths (Table 1). In Lake Managua: A tsunami triggered at Momotombito volcano would reach Mateare within 25 minutes and Managua after 70 minutes. In Lake Nicaragua: A tsunami due to an avalanche from Mombacho volcano would reach Granada almost immediately but would take about 90 minutes to reach the eastern shores. A tsunami generated by an avalanche at Concepción volcano on Ometepe Island would affect immediately the nearest beaches of the island but the wave would travel some tens of minutes to reach the opposite side of the island. We see that although tsunami waves travel slowly in the shallow lakes and the Nicaraguan lakes are rather large, warning times after a tsunamigenic event are short, particularly for communities close to the site of tsunami formation. Nevertheless, the times are quite comparable to those for tsunamis which threaten the towns on the Pacific coast of Nicaragua after very strong local earthquakes in the Nicaraguan subduction zone. In case of the 1992 tsunami at the Nicaraguan Pacific coast the first destructive wave impacted the beach about 45 to 60 minutes after the earthquake occurred. In recent years, the Nicaraguan geosciences institute (INETER) and Nicaraguan Civil Defense developed a tsunami warning for the Pacific coast of Nicaragua. Though tsunami hazard in the Pacific Ocean is certainly much higher, it might also make sense to think about tsunami warning for the shores of the large Nicaraguan lakes. For the tsunami warning in the Pacific Ocean, seismic stations are used as primary data sources pertaining to the occurrence of a large earthquake beneath the ocean which possibly could generate a tsunami. This method produces false alarms as not all large earthquakes generate tsunamis and it might fail completely for volcano and landslide-induced tsunamis in the lakes. 
Given the short tsunami travel times in the lakes, early warning mainly depends on timely recognition of possible trigger events. Though problematic with earthquakes, adequate monitoring can provide timely warning of volcanic eruptions and flank failure. Telemetric sea gauges may make use of the confined lake volume leading to a rise in lake level as a volcanic edifice in the lake inflates prior to eruption (or collapse). The problem of false alarms remains since it cannot be predicted with certainty if any of these events will actually produce a tsunami. A critical element in mitigating tsunami hazard at the lakes is public education. To quickly escape from near-shore areas, people must be aware that earthquakes and volcanic eruptions, which will be felt and seen by many of the population, may cause tsunamis.

In summary, tsunami hazard in the large Nicaraguan lakes exists due to manifold possible tsunami generation mechanisms related to volcanic eruptions and volcanic edifices. The risk level for the population might be relatively small in comparison with the risk due to direct effects of earthquakes, volcanic eruptions, and landslides or in comparison to tsunami risk on the Pacific coast of Nicaragua. Nevertheless, during ongoing volcanic eruptions the tsunami hazard might increase considerably and can be considered as the prevailing hazard for areas that would remain unaffected by other volcanic hazards. A tsunami warning system for the large lakes of Nicaragua might be developed as a part of a multi-purpose information and alert system on volcanic, meteorological and seismic phenomena. Public education, however, is crucial to achieve adequate response to such alerts.

\section{Acknowledgements}

Constructive comments from two referees helped to improve this paper. We thank the Direccion Hidrografia of INETER, Managua, for supplying bathymetric data of the lakes. This publication is contribution no. 95 of the Sonderforschungsbereich 574 on Volatiles and Fluids in Subduction Zones at Kiel University.

\section{REFERENCES}

Beget, J.E. Volcanic tsunamis. In (Sigurdsson H. et al. eds) Encyclopedia of Volcanoes. (Academic Press: 2000) pp. 1005-1014.

Belousov, A., Voight, B., Belousova, M., and Muravyev, Y. (2000), Tsunamis generated by subaquatic volcanic explosions: Unique data from 1996 eruption in Karymskoye Lake, Kamchatka, Russia, Pure Appl. Geophys. 157, 1135-1143.

Borgia, A. and van Wyk DE VRIES, B. (2003), The volcano-tectonic evolution of Concepcion, Nicaragua, Bull. Volcanol. 65, 248-266.

Brown, R.D., Ward, P.L., and Plafker, G. (1973), Geologic and seismologic aspects of the Managua, Nicaragua, earthquakes of December 23, 1972, US Geol. Surv. Prof. Paper 838, 34 p.

Carey, S., Morelli, D., Sigurdsson, H., and Bronto, S. (2001), Tsunami deposits from major explosive eruptions: An example from the 1883 eruption of Krakatau, Geology 29, 347-350. 
CARR, M.J. (1984), Symmetrical and segmented variation of physical and geochemical characteristics of the Central American volcanic front, J. Volcanol. Geotherm. Res. 20, 231-252.

Cowan, H., Prentice, C., Pantosti, D., de Martini, P., Strauch, W., and Workshop Participants (2002), Late Holocene earthquakes on the Aeropuerto Fault, Managua, Nicaragua, Bull. Seismol. Soc. Am. 92, 1694-1707.

De Lange, W.P., Prasetya, G.S., and Healy, T.R. (2001), Modelling of tsunamis generated by pyroclastic flows (ignimbrites), Natural Hazards 24, 251-266.

DeAn, R.G. and Dalrymple, R.A. Water wave mechanics for engineers and scientists, Adv. Ser. Ocean Engin. vol. 2 (World Scientific, Singapore, New Jersey 1991), pp. 1-353.

Dull, R., Stansell, N., Аввотt, M., and Lacayo, M.R. (2005), Lahar hazards and late Holocene paleoecology from Volcan Mombacho, Nicaragua, Abstract Paleobiogeography II.

Fernandéz, M., Molina, E., Havskov, J., and Atakan, K. (2000), Tsunamis and tsunami hazards in Central America, Natural Hazards 22, 91-116.

Freundt, A., Kutterolf, S., Wehrmann, H., Schmincke, H.-U., and Strauch, W. (2006a), Eruption of the dacite-to andesite-zoned Mateare Tephra, and associated tsunamis in Lake Managua, Nicaragua. J. Volcanol. Geotherm. Res. 149, 103-123.

Freundt, A., Kutterolf, S., Schmincke, H.-U., Hansteen, T.H., Wehrmann, H., Perez, W., Strauch, W., and Navarro, M. (2006b), Volcanic hazards in Nicaragua: Past, present, and future, GSA Spec. vol. 412 (in press).

FREUNDT, A. (2003), Entrance of hot pyroclastic flows into the sea: Experimental observations, Bull. Volcanol. 65, 144-164.

FREUNDT, A. (2006), Entrance of hot pyroclastic flows into the sea: Experimental tsunami formation, Bull. Volcanol. (in review).

FRITZ, H.M. (2002), Initial phase of landslide generated impulse waves, Ph.D. Thesis, ETH Zürich, Switzerland, ETH No. 14'871, 249 p.

Govi, M., Gulla, G., and Nicoletti, P.G. (2002), Val Pola rock avalanche of July 28, 1987 in Valtellina (Central Italian Alps). In (Evans, S.G., DeGraff, J.V. eds.) Catastrophic Landslides: Effects, Occurrence and Mechanisms, Reviews in Engineering Geology 15, 71-89.

HammaCK, J.L. (1973), A note on tsunamis: Their generation and propagation in an ocean of uniform depth, J. Fluid Mech. 60, 769-799.

Hart, K., Carey, S., Sigurdsson, H., Sparks, R.S.J., and Robertson, R.E.A. (2004), Discharge of pyroclastic flows into the sea during the 1996-1998 eruptions of the Soufriere Hills Volcano, Montserrat, Bull. Volcanol. 66, 599-614.

Ichinose, G.A., Anderson, J.G., Satake, K., Schweickert, R.A., and Lahren, M.M. (2000), The potential hazard from tsunami and seiche waves generated by large earthquakes within Lake Tahoe, California - Nevada, Geophys. Res. Lett. 27, 1203-1206.

KeAting, B.H. and McGuire, W.J. (2000), Island edifice failures and associated tsunami hazards, Pure Appl. Geophys. 157, 899-955.

Kerle, N. and VAn WyK DE VRIES, B. (2001), The 1998 debris avalanche at Casita Volcano, Nicaragua Investigation of structural deformation as the cause of slope instability using remote sensing, J. Volcanol. Geotherm. Res. 105, 49-63.

McCoy, F.W. and Heiken, G. (2000), Tsunami generated by the Late Bronze Age eruption of Thera (Santorini), Greece, Pure Appl. Geophys. 157, 1227-1256.

MCGuire, W.J. (2003), Volcano instability and lateral collapse, Revista 1, 33-45.

Miller, D.J. (1960), Giant waves in Lituya Bay, Alaska, US Geol. Surv. Prof. Paper 354-C, 1-86.

Molina, E. (1997), Tsunami catalogue for Central America 1539-1996, Report No. II 1-04, Institute of Solid Earth Physics, University of Bergen, Norway.

Müller, L. (1964), The rockslide in the Vaiont Valley, Rock Mech. Eng. Geol. 2, 148-212.

Newhall, C.G. and Dzurisin, D. (1988), Historical unrest at large calderas of the world, US Geol. Surv. Bull. 1855 (2 vol), 1108 p.

Pelinovsky, E., Zahibo, N., Dunkley, P., Edmonds, M., Herd, R., Talipova, T., Kozelkov, A., and NikolkinA, I. (2004), Tsunami generated by the volcano eruption on July 12-13, 2003 at Montserrat, Lesser Antilles, Sci. Tsunami Hazards 22, 44-57. 
Plafker, G. and Eyzaguirre, V.R. Rock avalanche and wave at Chungar, Peru. In (Voight, B. ed) Rockslides and Avalanches, vol. 2, Developments in Engineering Geology 14B (Elsevier, NL: 1979) 269279.

ReID, M.E., Sisson, T.W., and BRIEN, D.L. (2001), Volcano collapse promoted by hydrothermal alteration and edifice shape, Mount Rainier, Washington, Geology 29, 779-782.

Scott, K.M., Vallance, J.W., Kerle, N., Macias, J.L., Strauch, W., and Devoli, G. (2005), Catastrophic precipitation-triggered lahar at Casita Volcano, Nicaragua: Occurrence, bulking and transformation, Earth Surf. Process. Landforms 30, 59-79.

Self, S., Rampino, M.R., Newton, M.S., and Wolff, J.A. (1984), Volcanological study of the great Tambora eruption of 1815, Geology 12, 659-663.

SiEBERT, L. (2002), Landslides resulting from structural failure of volcanoes. In (Evans, S.G. and DeGraff, JV eds.) Catastrophic Landslides: Effects, Occurrence and Mechanisms, Rev. Engig. Geol. 15, $209-235$.

Sigurdsson, H. and CARey, S.N. (1989), Plinian and co-ignimbrite tephra fall from the 1815 eruption of Tambora volcano, Bull. Volcanol. 51, 243-270.

Slingerland, R.L. and Voight, B. Occurrences, properties and predictive models of landslide-generated tsunami waves. In (Voight, B., ed) Rockslides and avalanches, vol. 2, Developments in Engig. Geol. 14B (Elsevier, NL: 1979) pp.317-397.

Sussman, D. (1985), Apoyo Caldera, Nicaragua: A major Quaternary silicic eruptive center, J. Volcanol. Geotherm. Res. 24, 249-282.

Tinti, S., Bortolucci, E., and Armigliato, A. (1999), Numerical simulation of the landslide-induced tsunami of 1988 on Vulcano Island, Italy, Bull. Volcanol. 61, 121-137.

Vallance, J.W., Schilling, S.P., and Devoli, G. (2001a), Lahar hazards at Mombacho Volcano, Nicaragua, USGS Open File Report 01-455, 14 p.

Vallance, J.W., Schilling, S.P., Devoli, G., and Howell, M.M. (2001b), Lahar hazards at Concepción Volcano, Nicaragua, USGS Open File Report 01-457, 13 p.

Voight, B., Glicken, H., Janda, R.J., and Douglass, P.M. (1981), Catastrophic rockslide avalanche of May 18. In (P.W. Lipman and D.R. Mullineaux, eds), The 1980 eruptions of Mount St. Helens, Washington, US Geol. Survey Prof. Paper 1250, 347-377.

Wagner, T.P., McKee, C.O., Kuduon, J., and KombuA, R. (2003), Landslide-induced wave in a small volcanic lake: Kasu Tephra Cone, Papua New Guinea, Int. J. Earth Sci. 92, 405-406.

WAlder, J.S., Watts, P., Sorensen, O.E., and JAnssen, K. (2003), Tsunamis generated by subaerial mass flows, J. Geophys. Res. 108, 2236, doi: 10.1029/2001JB000707.

WATTS, P. (1998), Wavemaker curves for tsunamis generated by underwater landslides, J. Waterway Port Coastal and Ocean Engrg. 124, 127-137.

Waythomas, C.F. and Neal, C.A. (1998), Tsunami generation by pyroclastic flow during the 3500-year B.P. caldera-forming eruption of Aniakchak Volcano, Alaska, Bull. Volcanol. 60, 110-124.

(Received February 22, 2006, accepted July 30, 2006)

To access this journal online:

http://www.birkhauser.ch 